\title{
DETERMINING POTENTIAL CONFLICTS BETWEEN SMALL-SCALE FISHERIES AND SEA-CAGE FISH FARMS IN THE AEGEAN SEA
}

\author{
Okan AKYOL, Aytaç ÖZGÜL, Halil ŞEN, F. Ozan DÜZBASTILAR, \\ and Tevfik CEYHAN*
}

Ege University Faculty of Fisheries, Bornova, Izmir, Turkey

\begin{abstract}
Akyol O., Özgül A., Şen H., Düzbastılar F.O., Ceyhan T. 2019. Determining potential conflicts between small-scale fisheries and sea-cage fish farms in the Aegean Sea. Acta Ichthyol. Piscat. 49 (4): 365-372.

Background. Fish farms attract both juvenile and adult wild fishes in great numbers and diversity. These wild fishes also become an easy target stock for local fishers, both professional and recreational. There are three groups of interest in this study, the fish farmers, small-scale fishermen (professional), and recreational fishers (mostly anglers but also spear fishers). This study was intended to determine conflicts derived from the adverse social and bioecological interactions from the perspective of both local fishermen and fish farmers and to determine the observed incidence of predators.
\end{abstract}

Material and methods. In this study, 48 randomly selected fish farms, 28 fishery cooperatives, and 33 fishing ports located close to aquaculture areas were visited for face-to-face interviews with the fishermen of small-scale fisheries (SSF) between July 2015 and July 2017. The main purpose of the survey questionnaire was to ask SSF fishermen for their opinion about offshore aquaculture and vice versa — ask the fish farmers about SSF, emphasizing issues potentially creating problems. Data were collected mainly on sociodemographic profiles, current problems, reciprocal conflict issues, the impact of offshore fish farming on SSF activities, and on bioecological interactions such as predator attacks and problems with farm fish escapes.

Results. Approximately $77 \%$ of fishermen in Izmir and $71 \%$ of fishermen in Muğla declared that they had problems with the sea-cage fish farms. On the other hand, 40\% of fish farmers in Izmir and 54\% of fish farmers in Muğla reported problems with local SSF. The fishermen believe that in recent years, Mediterranean monk seal (Monachus monachus), sea turtle (Caretta caretta), and invasive fish (pufferfish, etc.) populations have been increasing in Muğla. Additionally, 46\% of Muğla fish farmers and 60\% of Izmir fish farmers acknowledged cases of fishes escaping from sea-cages. In terms of the predators, $84 \%$ of Muğla and $75 \%$ of Izmir's fishermen expressed their concerns regarding predator attacks on the sea-cage farms.

Conclusion. Further studies, based on socioeconomic issues, are needed for better understanding the dimensions of incomes and economic losses of SSF and cooperation issues in the area where the interaction is high. We suggest that all stakeholders, small-scale fishermen, in particular, must be integrated with a management plan, and the cooperation among both fishing groups should be encouraged.

Keywords: professional fisheries, recreational fisheries, user conflicts, marine aquaculture, predators, fish attraction

\section{INTRODUCTION}

Aquaculture and fisheries are activities that share the same ecosystem. There is a strong interaction between the two activities. Aquaculture may affect fisheries in positive ways, for example, by providing alternative livelihoods to fishermen including the postharvest processing and marketing of aquaculture products. In contrast, aquaculture may negatively affect fisheries through the disruption of natural habitats via eutrophication, the escape of farmed organisms, and the use of chemicals and fertilizers (Gowen 1994, Soto et al. 2008, Thorstad et al. 2008). Fish farms can also be considered very large fish aggregation devices (FAD) attracting both juvenile and adult wild fishes in great numbers and diversity. This aggregation influences the local ichthyofauna directly and fish stocks indirectly (Soto et al. 2012, Izquierdo-Gómez et al. 2014, Arechavala-Lopez et al. 2015, Izquierdo-Gómez et al. 2015, Barett et al. 2019). The stocks may be of interest to local fishermen (Sanchez-Jerez et al. 2007, FernandezJover et al. 2008), therefore, these displaced wild fish also become the target stock for local fishermen, who can catch them in large numbers and with low effort.

The Turkish aquaculture sector has been well developed since the 1970s. Marine aquaculture (or mariculture) started in 1985, and it has seen continuously rapid growth since then. In Turkey, total aquaculture production

* Correspondence: Dr T. Ceyhan, Ege Üniversitesi, Su Ürünleri Fakültesi, 35100 Bornova, Izmir, Turkey, phone: +90 2323115212 , fax: +90 232 388 3685, e-mail: (TC) tevfik.ceyhan@ege.edu.tr, (OA) okan.akyol@ege.edu.tr, (AO) aytac.ozgul@ege.edu.tr, (HS) halil.sen@ege.edu.tr, (FOD)f.ozan.duzbastilar@ege.edu.tr. 
and total mariculture production reached $276502 \mathrm{t}$ and 172492 t, respectively, in 2017 (Anonymous 2018a). At present, Turkey has become one of the ten major finfish producers in the world (Anonymous 2018b).

As the main cultured species, sea bass, Dicentrarchus labrax (Linnaeus, 1758), and gilthead seabream, Sparus aurata Linnaeus, 1758 , have a $93.4 \%$ share of the total mariculture production of Turkey (Anonymous 2018a). A total of 425 fish farms, including land ponds and hatcheries, exist in the Turkish mariculture sector (Anonymous 2017). The majority of these farms are located in the Aegean Sea in areas convenient for aquaculture. Provinces of Muğla (in the south) and Izmir (in the north) are two main mariculture locations along the Aegean coast of Turkey, with 78 sea-cage farms in the Izmir area, and 269 farms in the Muğla region.

Furthermore, a total of 3987 small-scale fishing (SSF) boats (i.e., gillnetters, seiners, beam-trawlers, longliners, and the others) in the Aegean Sea participate in daily fishing trips (Anonymous 2018a). The Aegean SSF fleet represents $30.3 \%$ of total number of SSF boats in all Turkish seas. In addition to SSF, recreational fishers also have fishing activities around the sea-cage fish farms. The coexistence of recreational fisheries with small-scale fisheries and fish farmers has been a source of conflicts.

In the Mediterranean, the fishing activities of both SSF and recreational fishers have been increasing steadily in the areas where the aquaculture facilities were deployed (Akyol and Ertosluk 2010, Bacher and Gordoa 2016). Formal regulation is needed to manage these maritime activities in Turkish coastal areas. However, due to the complexity and diversity of SSF and recreational fisheries, it would be challenging to implement effective regulations. This study was intended to determine social conflicts derived from the adverse social and bioecological interactions between fisheries and aquaculture and to ascertain the problems related to the aggregation of predator around the sea-cage fish farms.

\section{MATERIALS AND METHODS}

In this study, a total of 48 randomly selected fish farms were visited, of which 20 were in the proximity of Izmir and 28 in the Muğla area (Fig. 1). The studied farms ranged from 1.2 to 200 thousand $\mathrm{m}^{2}$ in area, and consisted of 4 to 220 offshore cages, deployed at depths of 35-60 m. The total production ranged from 140 to $5200 \mathrm{t}$ per farm per year.

Additionally, a total of 28 fishery cooperatives and 33 fishing ports, located close to the aquaculture areas were visited to interview face-to-face cooperative managers and SSF fishermen. All necessary permits for this survey were obtained from the Scientific Research and Publication Ethics Board of the Ege University and all fish farmers and SSF fishermen interviewed were informed about the confidentiality of the personal data and their interview responses. The interviews were performed during approximately $10 \mathrm{~min}$ by two authors for SSF and fish farmers separately. A total of 329 fishermen, with 153 from Muğla and 176 from Izmir, were questioned between July 2015 and July 2017. As a result of interviews with fish farmers and SSF fishermen in both areas, a total of 377 questionnaires were gathered. The interviewed professionals represent approximately $11 \%$ and $13 \%$ of the active small-scale fishermen and fish farms, respectively.

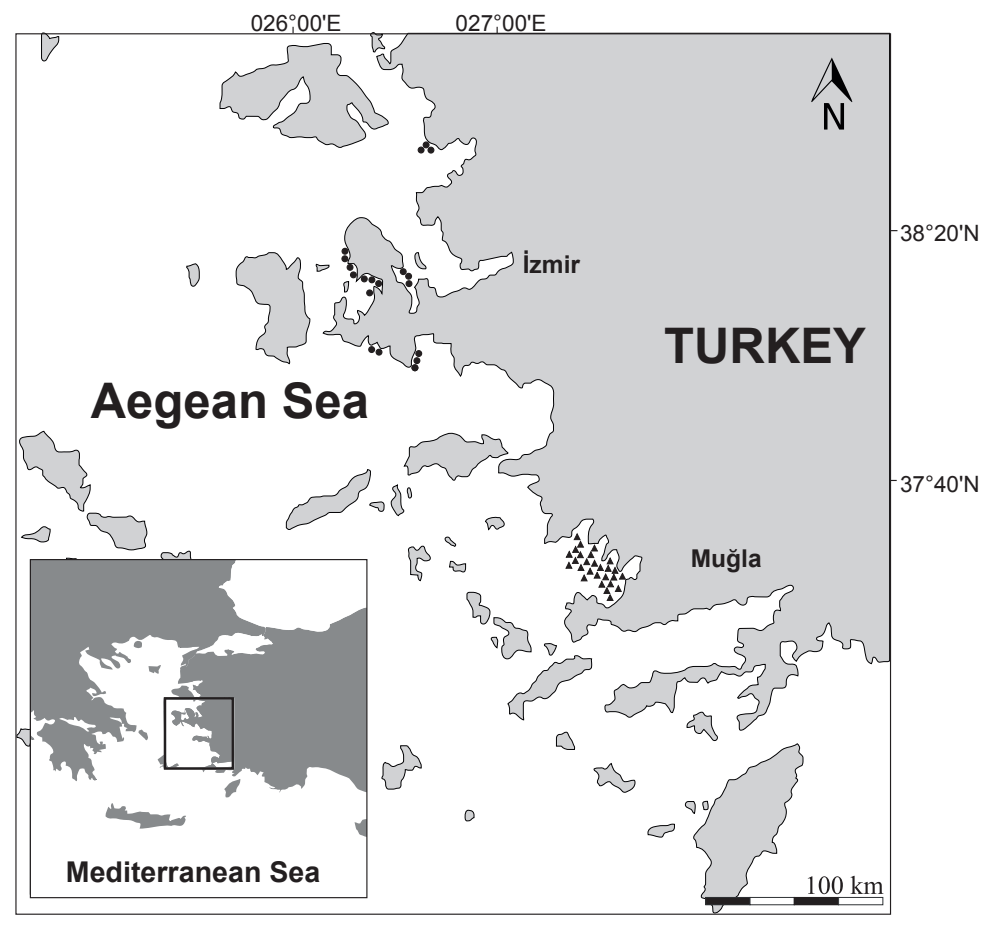

Fig. 1. Map of fish farms studied in the Aegean Sea (black dots show approximate locality of each sea-cage fish farm) 
The questionnaire for SSF fishermen contained questions related to offshore aquaculture and vice versa, the survey form for fish farmers ask for their opinions about SSF. The questions asked were related to some sociodemographic profiles, current problems and mutual conflict issues, the impact of the offshore fish farming on SSF activities, and bioecological interactions such as predator attacks and fish escape problems.

Chi-square $\left(\chi^{2}\right)$ tests were performed to test differences between regions in answers given to the questions. The significance level $\alpha$ for a given hypothesis in all statistical tests performed in this study was 0.05 . All mean values were given with standard error $( \pm \mathrm{SE})$. All calculations were performed using the IBM SPSS Statistics Ver. 2.0 software package.

\section{RESULTS}

There are three groups of interest in this study, the fish farmers, small-scale fishermen (professional), and recreational fishers (mostly anglers but also spear fishers). The fishermen age ranged from 20 to 71 years (mean \pm $\mathrm{SD}=49.2 \pm 0.85$ ) in Izmir region, and between 27 and 78 years $(48.8 \pm 0.83)$ in Muğla region. Their fishing experience ranged from 6 to 60 years $(29.5 \pm 1.1)$ in the Izmir region, and 8 to 60 years $(31.1 \pm 0.96)$ in Muğla region. $84 \%$ of fishermen were members of a fishery cooperative in both areas.

Approximately 77\% fishermen in Izmir and 71\% fishermen in Muğla stated that they had problems with the sea-cage fish farms. In terms of fish farmers, $40 \%$ of those from Izmir and 54\% from Muğla reported problems with SSF. In total, $53.8 \%$ of SSF claimed that they had net damages, caused by aquaculture equipment (e.g., vaults, anchors, and moorings). The conflicting issues for both groups are shown in Fig. 2. The water pollution caused by fish farms results from the substrate pollution beneath the sea-cages by the accumulation of unused fish feed and fish excrements. Such bottom deposits are deadly for marine flora and demersal fauna.

In contrast, some SSF fishermen stated that there are some positive sides of sea-cage fish farms such as the enhancement of fish populations, especially pelagic fishes, and exclusion of a large-scale fishery in the area. However, numbers of SSF fishermen operating around sea-cages are between 25 and 50 people per day and recreational fishers reach 650 people, especially on weekends in Muğla region. Many of fishing boats get tourism licenses to work as a charter for recreational fishers. Therefore, the boats carry the recreational fishers to areas around the seacage fish farms for fishing activities. This phenomenon is a significant complaint subject of the fish farmers. According to them, the numbers of recreational fishing boats around the sea-cage farms ranged from 6 to 450 in Muğla and from 3 to 60 in Izmir regions.

Proportionally, $60 \%$ of fishermen in Izmir and $71 \%$ fishermen in Muğla reported a problem with recreational fishers, and $65 \%$ of fish farmers in Izmir and $57 \%$ of fish farmers in Muğla stated their problem about the same issue. Recreational fishers around the sea-cage fish farms were the main problem for both groups. Major complaints, stated by all interviewed, were indicated in Fig. 3.

$59 \%$ fishermen from Muğla and $41 \%$ of fishermen from Izmir declared that fish farms might enhance the fish abundance in the area. Around the sea-cage fish farms in both regions, the following fish species were commonly reported: bogue, Boops boops (Linnaeus, 1758); bluefish, Pomatomus saltatrix (Linnaeus, 1766); European seabass, Dicentrarchus labrax; and salema, Sarpa salpa (Linnaeus, 1758). Others were Atlantic chub mackerel, Scomber colias Gmelin, 1789; Mugil spp., gilthead sea bream, Sparus

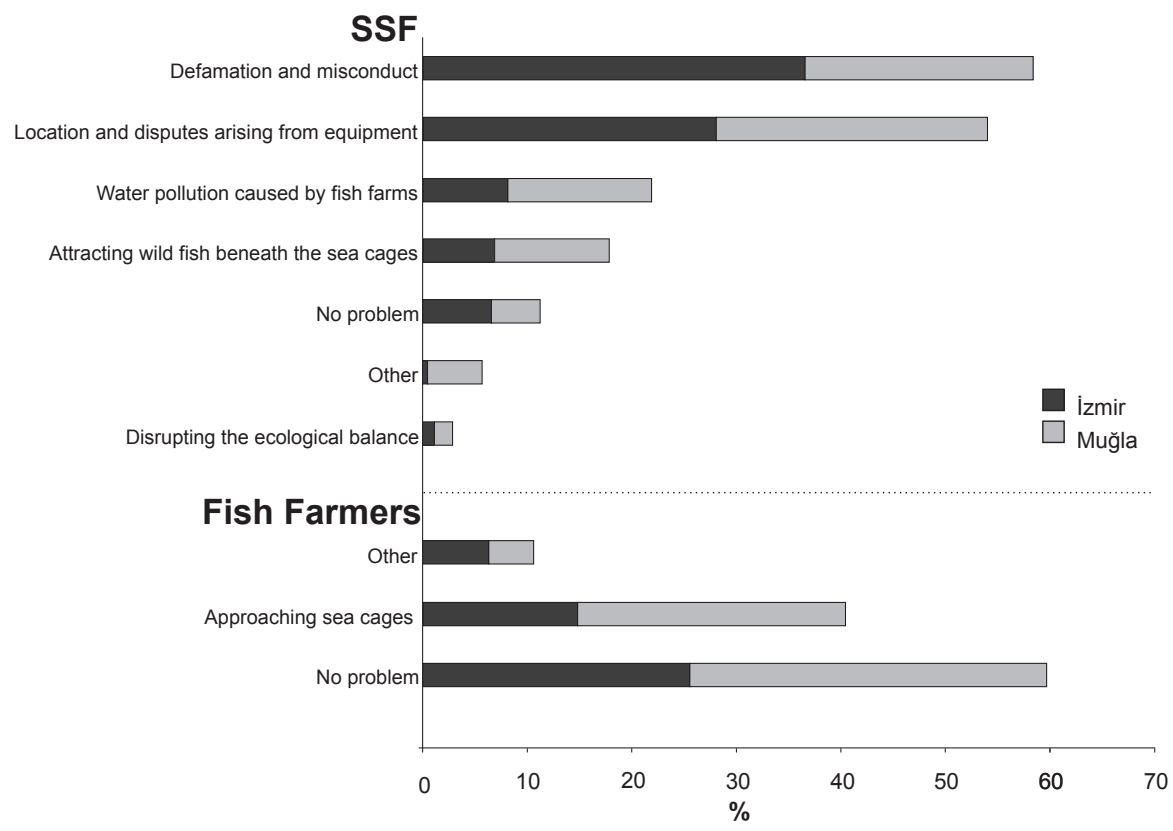

Fig. 2. The proportions of issues of conflict in the Aegean Sea reported by small-scale fisheries (SSF) and fish farmers from Izmir and Muğla areas, Turkey 
aurata; Atlantic bluefin tuna, Thunnus thynnus (Linnaeus, 1758); white seabream, Diplodus sargus (Linnaeus, 1758); and blotched picarel, Spicara maena (Linnaeus, 1758).

As many as $95 \%$ of Muğla and $70 \%$ of Izmir's SSF fishermen admitted that their fishing operations occur around the sea-cage fish farms, especially gillnet fishery for bogue, Boops boops. The other target fishes include red mullets, Mullus sp.; grey mullets, Mugil spp.; common pandora, Pagellus erythrinus (Linnaeus, 1758); red porgy, Pagrus pagrus (Linnaeus, 1758); common dentex, Dentex dentex (Linnaeus, 1758); gilthead sea bream, Sparus aurata; bluefish, Pomatomus saltatrix; saddled seabream, Oblada melanura (Linnaeus, 1758); sand steenbras, Lithognathus mormyrus (Linnaeus, 1758); garfish, Belone belone (Linnaeus, 1760); common octopus, Octopus vulgaris; and European squid, Loligo vulgaris. Moreover, $79 \%$ fish farmers of Muğla and 100\% of fish farmers of Izmir confirmed that there were fishing activities performed by SSF and recreational fishers around their sea-cage fish farms. According to fish farmers, the targeted wild species were the same as earlier mentioned. However, they added different fishes such as the round sardinella, Sardinella aurita Valenciennes, 1847; common dolphinfish, Coryphaena hippurus Linnaeus, 1758; rabbitfish, Siganus sp; and Atlantic bonito, Sarda sarda (Bloch, 1793), to the list.

Additionally, $46 \%$ of Muğla and $60 \%$ of Izmir fish farmers mentioned fish escapes from sea-cages. The fish escapes occurred due to damages to cage nets, storms, fish fall from dipnets during the harvesting, and predator attacks. Furthermore, damages to cage nets, caused particularly by monk seal and bluefish depredation, were also reported by $18 \%$ of Muğla and $40 \%$ of Izmir fish farmers. These events were one of the sources of significant economic losses. Indeed, the losses of fish during the last year were approximately 5000 (more than $4 \mathrm{t})$ seabass in Muğla region, and 1000 gilthead seabream and 20000 seabass in the Izmir region.
In terms of the predators, $84 \%$ of Muğla and $75 \%$ of Izmir fishermen mentioned predator attacks to the seacage farms. The common predators were dolphins, monk seals, bluefin tuna, bluefish, sharks, and sea turtles. Table 1 shows the observed incidences of predators around the sea-cage fish farms. Regionally, there is a significant difference between the observed incidences of monk seals for both regions $(P<0.05)$. Bluefin tuna and sharks were the main predators in Muğla region (south-eastern Aegean Sea). In contrast, seals and dolphins were the main predators in the Izmir region (mid-eastern Aegean Sea). Rarely, sea turtles and sharks were attracted to sea cages. Although $9 \%$ of fishermen observed sea turtles and sharks in the Izmir region, $8 \%$ of fishermen saw sea turtles in Muğla region. An increase in predator abundance was also mentioned by $18 \%$ and $55 \%$ of fish farmers in Muğla and Izmir, respectively.

In addition to conflicts between fish farmers and SSF, a significant increase of dolphins (i.e., Delphinus delphis, Tursiops truncatus, and Stenella coeruleoalba) has been reported by both groups. Moreover, they believe that Mediterranean monk seal (Monachus monachus), sea turtle (Caretta caretta), and invasive fish (pufferfish etc.) populations have been increasing in Muğla region.

\section{DISCUSSION}

We determined that about three-quarters of smallscale fishermen had a problem with sea-cage fish farms, and almost half of the fish farmers had a problem with SSF. In brief, the complaint issues concentrated on water pollution, fish attraction phenomenon of sea cages, space limitation for fishing, and the attraction of dolphins to the area. The recreational fishers had also problems with both SSF and aquaculture units. In spite of having a daily quota of $5 \mathrm{~kg}$, the majority of them have been exceeding the daily allowance with the intention to sell the excess of their catch for profit. Moreover, the recreational fishers have been entering aquaculture areas not only to catch

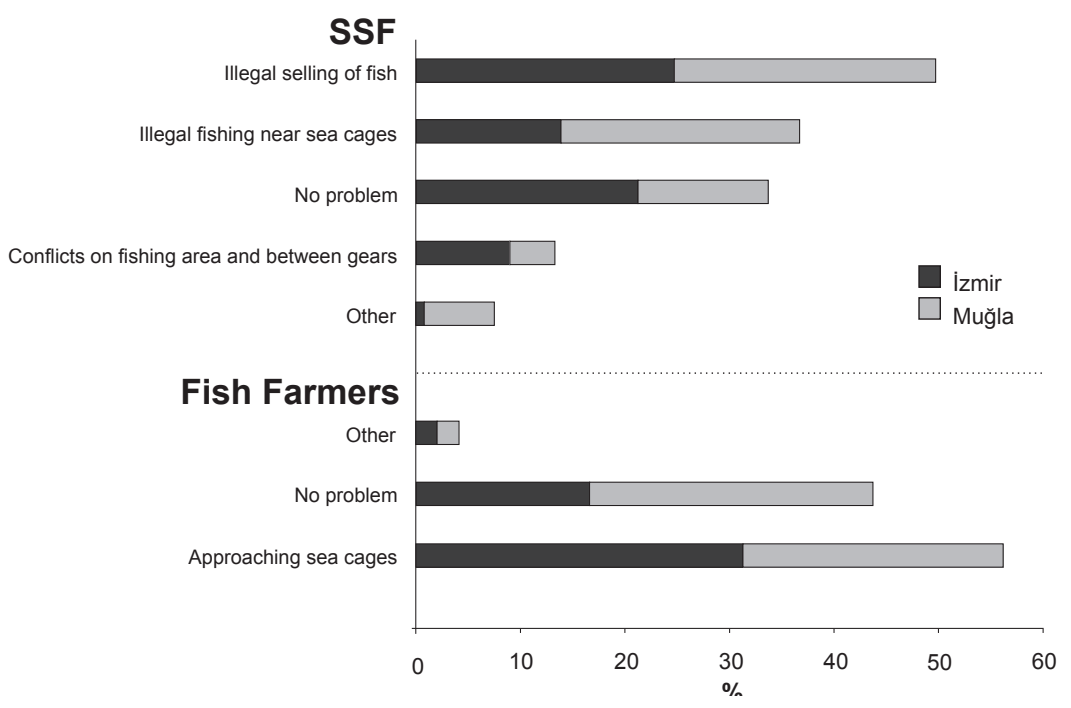

Fig. 3. Main issues of conflict related to recreational fishers in the Aegean Sea, reported by small-scale fisheries (SSF) and fish farmers from Izmir and Muğla areas, Turkey 
Table 1

The observation incidence ratio of the some predators around the sea-cage fish farms in the Aegean Sea (\% of expressions)

\begin{tabular}{|c|c|c|c|c|c|c|c|}
\hline \multirow[b]{2}{*}{ Area } & \multirow[b]{2}{*}{ Incidence } & \multicolumn{6}{|c|}{ Predator species } \\
\hline & & Dolphin & $\begin{array}{l}\text { Monk seal } \\
(P<0.05)\end{array}$ & Bluefish & Tuna & Sea turtle & Shark \\
\hline \multirow{4}{*}{ 志 } & Persistent & 87.0 & 4.3 & 0.0 & 17.4 & 0.0 & 0.0 \\
\hline & Seasonal & 8.7 & 4.3 & 4.3 & 39.1 & 8.7 & 8.7 \\
\hline & Rare & 0.0 & 21.7 & 8.7 & 0.0 & 0.0 & 0.0 \\
\hline & None & 4.3 & 69.6 & 87.0 & 43.5 & 91.3 & 91.3 \\
\hline \multirow{4}{*}{$\stackrel{\frac{\pi}{000}}{\stackrel{100}{z}}$} & Persistent & 84.0 & 32.0 & 0.0 & 0.0 & 0.0 & 0.0 \\
\hline & Seasonal & 8.0 & 28.0 & 40.0 & 48.0 & 8.0 & 0.0 \\
\hline & Rare & 0.0 & 12.0 & 0.0 & 0.0 & 0.0 & 0.0 \\
\hline & None & 8.0 & 28.0 & 60.0 & 52.0 & 92.0 & 100.0 \\
\hline
\end{tabular}

fish on hook and rod but also to dive with light at night, as well. However, there are space limitations $(200 \mathrm{~m}$ to the sea cages) and restrictions of using a light source for underwater spear fishing (Anonymous 2016).

The main problems of coastal fishing activities, as highlighted by SSF, were the pollution caused by fish farms, the space limitation for fishing, recreational fishers, and net damage caused particularly by dolphins and monk seals. In contrast to accepting recreational fishers as a kind of problem by SSF, many of fishing boats get tourism licenses to work as a charter for recreational fishers. Therefore, the boats carry the recreational fishers to areas around the sea-cage fish farms for fishing activities. Furthermore, the pescatourism might be an extra income for SSF in Turkey. Piasecki et al. (2016) stated that the pescatourism activity can bring about various profits to the coastal (fisheries) communities, local authorities and self-governments, and obviously tourists. However, the current regulations do not permit any non-professional visitors on board of fisheries vessels.

Pardalou and Tsikliras (2018) stated that the interactions between dolphins and coastal fisheries were a 'hot' issue that has economic, social, and ethical dimensions in the Mediterranean Sea. The growing abundance of dolphins increases the chances of gillnet damage. Villasante et al. (2019) stated that SSF in Thermaikos Gulf (Greece) competed with dolphins which constantly destroy their fishing gear (nets) and damage the captured fish. The dolphin attacks cause a decrease of soak time, as well as the damage to nets and captured fish (Pardalou and Tsikliras 2018, Villasante et al. 2019). In terms of economic losses, Bearzi et al. (2011) stated that the economic cost of net damage caused by dolphins was $€ 1000$ per year in Italy. The most frequently reported cost of economic losses also ranged from $€ 500$ to $€ 1000$ in Greece (Gonzalvo et al. 2015). There is a lack of information about the economic losses caused by the fish depredation by dolphins in the Turkish seas. We think that it may have reached the high economic losses as reported from the other countries.

Bluefish, Pomatomus saltatrix, are migratory pelagic predators that are distributed over continental shelves and in estuaries of temperate waters throughout most of the world (Juanes et al. 1996). Schools of bluefish occur beneath coastal net-pens in farming areas and bluefish may enter the sea cages through existing holes or by biting new holes to prey on the cultured fish (ArechavalaLopez et al. 2015). Sanchez-Jerez et al. (2008) reported that the bluefish (ranging from 10 to 100 individuals, and TL range: $30-70 \mathrm{~cm}$ ) attacked repeatedly three times a year in Turkey. In this study, the bluefish attacks to the seacage farms were also expressed in both regions studied. The attacks were responsible for more than 20000 fish that escaped last year. Bluefish individuals seem to find an optimal foraging habitat around Mediterranean fish farms (Arechavala-Lopez et al. 2015). Therefore, the owners of fish farms should take into consideration the possibility of increasing bluefish attacks to the cages in future.

The increasing incidences of fish-farm attacks by the Mediterranean monk seal in recent years were also reported by fish farmers in the Muğla region. The last study also verified this phenomenon with six sightings of monk seals from three fish farms in Muğla and a single specimen from one fish farm in the Izmir region (Gerovasileiou et al. 2017). Previously, a total of 40 attacks on 11 fish farms in the Turkish Aegean Sea between 1992 and 2000, which resulted in damage to cage nets and the escape of farmed fishes, have been reported by Güçlüsoy and Savas (2003). The interaction between monk seals and marine aquaculture is a well-known occurrence and M. monachus sometimes becomes one of the major problems for fish farms due to attacks on fishes in cages.

Some fish escaping from sea-cages can be caught easily by small-scale fishermen (I. Temiztepe and Ş. Kan, personal communication). Izquierdo-Gomez and SanchezJerez (2016) stated that fisheries can play an active role in mitigating the genetic and competition risks posed by escaped farm fish. For example, artisanal fisheries were successful in recapturing over $60 \%$ of the biomass following a large escape event of gilthead seabream in the Mediterranean. However, there is a lack of studies on the impact of the escaped fish in the Aegean Sea. To assess the impact of escapes, the number of escaped fish from aquaculture and the percent decline in native fishes should be known (Anonymous 2008).

The nutrients originating from sea-cage aquaculture have resulted in enhanced primary productivity, leading 
to increases in wild fish populations and a doubling of fisheries landings in regions with fish farms as opposed to regions without fish farms (Machias et al. 2005, 2006). Many of the fish species that occur at sea-cage fish farms are commercially important for SSF and are already subject to heavy fishing pressure. Especially, the professional gillnet fishery for bogue is very popular, as is handline fishery for sparids and carangids around the sea-cage fish farms in Turkey. Increased commercial and recreational fishing around fish farms has been reported in Spain, as well (Fernandez-Jover et al. 2007, ArechavalaLopez et al. 2011, Bacher and Gordoa 2016). Recreational fishing pressure peaked during the summer (or holiday) season, but commercial fishing activity around the seacage farms did not show any seasonal pattern (Bacher and Gordoa 2016). In the presently reported study, a similar activity of recreational fishers has been observed, namely, recreational fishing near sea-cage farms increases during both summer season and weekends. However, SSF around the fish farms usually concentrates during the spawning season of bogue between December and April and decreases during the summer season after the movement of spawned bogue to beneath sea-cages because SSF cannot approach sea-cage farms owing to the legal protection zone of $200 \mathrm{~m}$ around a sea-cage.

SSFs are characterized by the usage of diverse fishing gear and the targeting of multiple species in Greece (Villasante et al. 2019), as well as Turkey. However, the presently reported findings are in line with previous studies, indicating that the majority of Mediterranean and Black Sea stocks are overexploited (Vasilakopoulos et al. 2014, Cardinale et al. 2017). The specific nature of the Aegean demersal fishery results from the fact that the majority of landings and profit come from a large number of species, for which no assessments are available due to lack of data (Sgardeli et al. ${ }^{*}$ ). Moreover, SSF in the Aegean Sea focuses on the wild fish stocks around the sea cage fish farms, owing to abundant, readily accessible fish. However, we think that these stocks around the seacages may be the last ones under protection. Because of that, the management of the marine resources would be more efficient through fleet capacity control schemes, improvement of selectivity, and protection of nursery grounds as this would ensure the viability of all fleet segments and promote sustainable fisheries (Tserpes et al. 2016, Christou et al. 2019). Furthermore, we suggest that the wild fish stocks around the sea cage fish farms should be taken into account by fishery management plans.

In conclusion, this study presents some conflicts between aquaculture and SSF in the Aegean Sea. Since 2007, the sea-cage farms have been forced to the open sea at least $1 \mathrm{~km}$ away from the shoreline (Anonymous 2007). Although this case opens space for SSF, the fishermen are displeased because the wild fish stocks move to the proximity of the sea-cages. The other negative impacts, such as those of recreational fishing, water pollution, disruption of the ecology and habitat, misconduct of fish farmers, and the attraction of dolphins caused by fish farms are ongoing, according to SSF. A wide range of conservation, management, and protection measures have been advocated and introduced in fisheries under an ecosystem approach (Morishita 2008). Ecosystem approach fisheries management should cover economic, social, and cultural benefits that can be derived from fisheries resources (Anonymous 2003). Therefore, further studies based on socioeconomic issues are needed for better understanding of the dimensions of incomes and economic losses of SSF and cooperation issues in the areas where the interaction is high. The implementation of an operational plan covers what would need to be done and by whom, when, and where. Moreover, this plan must include the timing, the resources (human and financial), the institutions and stakeholders that need to work together, and it must consider the practicality or feasibility of the proposed management arrangements (Soto et al. 2012). We suggest that all stakeholders in particular small-scale fishermen, must be integrated with a management plan of the Aegean Sea and the cooperation among both fishing groups should be encouraged in Turkey.

\section{ACKNOWLEDGEMENTS}

This study was financially supported by the Scientific and Technological Research Council of Turkey (TUBITAK) [Project number: 114Y584].

\section{REFERENCES}

Akyol O., Ertosluk O. 2010. Fishing near sea-cage farms along the coast of the Turkish Aegean Sea. Journal of Applied Ichthyology 26 (1): 11-15. DOI: 10.1111/j.1439-0426.2009.01348.x

Anonymous 2003. The ecosystem approach to fisheries. FAO Technical Guidelines for Responsible Fisheries No. 4, Suppl. 2. FAO, Rome.

Anonymous 2007. Denizlerde Balık Çiftliklerinin Kurulamayacağı Hassas Alan Niteliğindeki Kapalı Koy Ve Körfez Alanlarının Belirlenmesine İlişkin Tebliğ [Notification to Identify The Closed Bays and Gulfs Qualified As Sensitive Areas Where Fish Farms Are Not Allowed.] T.C. Resmi Gazete. [Turkish Official Gazette.] No. 26413 [In Turkish.]

Anonymous 2008. Aquaculture development. 3. Genetic resource management. FAO Technical Guidelines for Responsible Fisheries. No. 5, Suppl. 3. FAO, Rome.

Anonymous 2016. 4/2 Numaralı Amatör Amaçlı Su Ürünleri Avcılığının Düzenlenmesi Hakkında Tebliğ [Notification $4 / 2$ on recreational fisheries.] G1da, Tarım ve Hayvancılık Bakanlığından. [Ministry of Food, Agriculture and Livestock.] Tebliğ No: 2016/36 [Notification No. 2016/26] [In Turkish.]

Anonymous 2017. Balıç̧ılık İstatistikleri [Fisheries Statistics.] Gıda, Tarım ve Hayvancılık Bakanlığı Balıkçılık ve Su Ürünleri Genel Müdürlüğü, Gıda, Tarım ve Hayvancılık Bakanlığından. [Ministry of Food, Agriculture and Livestock-General Directorate of Fisheries and Aquaculture.] [Accessed date: 3 August 2017.] [In Turkish.] http://tarim.gov.tr/BSGM 
Anonymous 2018a. 2017 Su Ürünleri İstatistikleri [Fisheries Statistics in 2017]. (accessed date: 12 Sept. 2018). [In Turkish.] https://www.tuik.gov.tr

Anonymous 2018b. The state of world fisheries and aquaculture 2018. Meeting the sustainable development goals. FAO, Rome.

Arechavala-Lopez P., Izquierdo-Gomez D., Uglem I., Sanchez-Jerez P. 2015. Aggregations of bluefish Pomatomus saltatrix (L.) at Mediterranean coastal fish farms: seasonal presence, daily patterns and influence of farming activity. Environmental Biology of Fishes 98 (2): 499-510. DOI: 10.1007/s10641-014-0280-5

Arechavala-Lopez P., Sánchez-Jerez P., Bayle-Sempere J., Fernandez-Jover D., Martinez-Rubio L., LopezJimenez J.A., Martinez-Lopez F.J. 2011. Direct interaction between wild fish aggregations at fish farms and fisheries activity at fishing grounds: A case study with Boops boops. Aquaculture Research 42 (7): 996-1010. DOI: 10.1111/j.1365-2109.2010.02683.x

Bacher K., Gordoa A. 2016. Does marine fish farming affect local small-scale fishery catches? A case study in the NW Mediterranean Sea. Aquaculture Research 47 (8): 2444-2454. DOI: 10.1111/are.12692

Barrett L.T., Swearer S.E., Dempster T. 2019. Impacts of marine and freshwater aquaculture on wildlife: A global meta-analysis. Reviews in Aquaculture 11 (4): 1022-1044. DOI: 10.1111/raq.12277

Bearzi G., Bonizzoni S., Gonzalvo J. 2011. Dolphins and coastal fisheries within a marine protected area: Mismatch between dolphin occurrence and reported depredation. Aquatic Conservation: Marine and Freshwater Ecosystems 21 (3): 261-267. DOI: 10.1002/aqc. 1179

Cardinale M., Osio C.C., Scarcella G. 2017. Mediterranean Sea: A failure of the European fisheries management system. Frontiers in Marine Science 4: e72. DOI: 10.3389/fmars.2017.00072

Christou M., Maynou F., Tserpes G., Stergiou K.I., Maravelias C.D. 2019. "Crash landing" obligation for Mediterranean mixed fisheries: Evaluation of management strategies using bioeconomic modelling in the Aegean Sea. Scientia Marina 83 (2): 143-154. DOI: $10.3989 /$ scimar.04881.08A

Fernandez-Jover D., Lopez Jimenez J.A., SanchezJerez P., Bayle-Sempere J., Gimenez Casalduero F., Martinez Lopez F.J., Dempster T. 2007. Changes in body condition and fatty acid composition of wild Mediterranean horse mackerel (Trachurus mediterraneus, Steindachner, 1868) associated to sea cage fish farms. Marine Environmental Research 63 (1): 1-18. DOI: 10.1016/j.marenvres.2006.05.002

Fernandez-Jover D., Sanchez-Jerez P., Bayle-Sempere J.T., Valle C., Dempster T. 2008. Seasonal patterns and diets of wild fish assemblages associated with Mediterranean coastal fish farms. ICES Journal of Marine Science 65 (7): 1153-1160. DOI: 10.1093/icesjms/fsn091

Gerovasileiou V., Akel E.H.Kh., Akyol O., Alongi G., Azevedo F., Babali N., Bakiu R., Bariche M., Bennoui A., Castriota L., Chintiroglou C.C., Crocetta F.,
Deidun A., Galinou-Mitsoudi S., Giovos I., Gökoğlu M., Golemaj A., Hadjioannou L., Hartingerova J., Insacco G., Katsanevakis S., Kleitou P., Korun J., Lipej L., Malegue M., Michailidis N., Mouzai Tifoura A., Ovalis P., Petovic S., Piraino S., Rizkalla S.I., Rousou M., Savva I., Şen H., Spinelli A., Vougioukalou K.G., Xharahi E., Zava B., Zenetos A. 2017. New Mediterranean Biodiversity Records (July 2017). Mediterranean Marine Science 18 (2): 355-384. DOI: $10.12681 / \mathrm{mms} .13771$

Gonzalvo J., Giovos I., Moutopoulos D.K. 2015. Fishermen's perception on the sustainability of smallscale fisheries and dolphin-fisheries interactions in two increasingly fragile coastal ecosystems in western Greece. Aquatic Conservation: Marine and Freshwater Ecosystems 25 (1): 91-106. DOI: 10.1002/aqc.2444

Gowen R.J. 1994. Managing eutrophication associated with aquaculture development. Journal of Applied Ichthyology 10 (4): 242-257. DOI: 10.1111/j.14390426.1994.tb00164.x

Güçlüsoy H., Savas Y. 2003. Interaction between monk seal Monachus monachus (Hermann, 1779) and marine fish farms in the Turkish Aegean and management of the problem. Aquaculture Research 34 (9): 777-783. DOI: 10.1046/j.1365-2109.2003.00884.X

Izquierdo-Gómez D., González-Silvera D., ArechavalaLópez P., López-Jiménez J.Á., Bayle-Sempere J.T., Sánchez-Jerez P. 2014. Exportation of excess feed from Mediterranean fish farms to local fisheries through different targeted fish species. ICES Journal of Marine Science 72 (3): 930-938. DOI: 10.1093/icesjms/fsu179

Izquierdo-Gomez D., Sanchez-Jerez P. 2016. Management of fish escapes from Mediterranean Sea cage aquaculture through artisanal fisheries. Ocean and Coastal Management 122: 57-63. DOI: 10.1016/j. ocecoaman.2016.01.003

Izquierdo-Gomez D., Sanchez-Jerez P., Bayle-Sempere J., Loader N., Garcia de Leaniz C. 2015. Effects of coastal fish farms on body size and isotope composition of wild penaeid prawn. Fisheries Research 172: 50-56. DOI: 10.1016/j.fishres.2015.06.017

Juanes F., Hare J.A., Miskiewicz A.G. 1996. Comparing early life history strategies of Pomatomus saltatrix: A global approach. Marine and Freshwater Research 47 (2): 365-379. DOI: 10.1071/mf9960365

Machias A., Giannoulaki M., Somarakis S., Maravelias C.D., Neofitou C., Koutsoubas D., Papadopoulou K.N., Karakassis I. 2006. Fish farming effects on local fisheries landings in oligotrophic seas. Aquaculture 261 (2): 809-816. DOI: 10.1016/j. aquaculture.2006.07.019

Machias A., Karakassis I., Giannoulaki M., Papadopoulou K.N., Smith C.J., Somarakis S. 2005. Response of demersal fish communities to the presence of fish farms. Marine Ecology Progress Series 288: 241-250. DOI: $10.3354 / \operatorname{meps} 288241$

Morishita J. 2008. What is the ecosystem approach for fisheries management? Marine Policy 32 (1): 19-26. DOI: 10.1016/j.marpol.2007.04.004 
Pardalou A., Tsikliras A.C. 2018. Anecdotal information on dolphin-fisheries interactions based on empirical knowledge of fishers in the northeastern Mediterranean Sea. Ethics in Science and Environmental Politics 18: 1-8. DOI: 10.3354/esep00179

Piasecki W., Gląbiński Z., Francour P., Koper P., Saba G., Molina García A., Ünal V., Karachle P.K., Lepetit A., Tservenis R., Kızllkaya Z., Stergiou K.I. 2016. Pescatourism-A European review and perspective. Acta Ichthyologica et Piscatoria 46 (4): 325-350. DOI: 10.3750/AIP2016.46.4.06

Sanchez-Jerez P., Bayle-Sempere J., FernandezJover D., Valle C., Dempster T. 2007. Ecological relationship between wild fish populations and Mediterranean aquaculture in floating fish cages. Pp. 77-80. In: Briand F. (ed.) Impact of mariculture on coastal ecosystems, Lisboa, 21-24 February 2007. CIESM Workshop Monographs No. 32.

Sanchez-Jerez P., Fernandez-Jover D., Bayle-Sempere J., Valle C., Dempster T., Tuya F., Juanes F. 2008. Interactions between bluefish Pomatomus saltatrix (L.) and coastal sea-cage farms in the Mediterranean Sea. Aquaculture 282: 61-67. DOI: 10.1016/j. aquaculture.2008.06.025

Soto D., Aguilar-Manjarrez J., Brugère C., Angel D., Bailey C., Black K., Edwards P., Costa-Pierce B., Chopin T., Deudero S., Freeman S., Hambrey J., Hishamunda N., Knowler D., Silvert W., Marba N., Mathe S., Norambuena R., Simard F., Tett P., Troell M., Wainberg A. 2008. Applying an ecosystem-based approach to aquaculture: Principles, scales and some management measures. Pp. 15-35. In: Soto D., Aguilar-Manjarrez J., Hishamunda N. (eds.) Building an ecosystem approach to aquaculture. FAO/ Universitat de les Illes Balears Expert Workshop. 7-11 May 2007, Palma de Mallorca, Spain. FAO Fisheries and Aquaculture Proceedings No. 14. FAO, Rome.

Soto D., White P., Dempster T., De Silva S., Flores A., Karakassis Y., Knapp G., Martinez J., Miao
W., Sadovy Y., Thorstad E., Wiefels R. 2012. Addressing aquaculture-fisheries interactions through the implementation of the ecosystem approach to aquaculture (EAA). Pp. 385-436. In: Subasinghe R.P., Arthur J.R., Bartley D.M., De Silva S.S., Halwart M., Hishamunda N., Mohan C.V., Sorgeloos P. (eds.) Farming the waters for people and food. Proceedings of the Global Conference on Aquaculture 2010, 22-25 September 2010, Phuket, Thailand. FAO, Rome and NACA, Bangkok, Thailand.

Thorstad E.B., Fleming I.A., McGinnity P., Soto D., Wennevik V., Whoriskey F. 2008. Incidence and impacts of escaped farmed Atlantic salmon Salmo salar in nature. Report from the Technical Working Group on Escapes of the Salmon Aquaculture Dialogue, January 2008. NINA Special Report No. 36.

Tserpes G., Nikolioudakis N., Maravelias C., Carvalho N., Merino G. 2016. Viability and management targets of Mediterranean demersal fisheries: The case of the Aegean Sea. PLoS ONE 11 (12): e0168694. DOI: 10.1371/journal.pone.0168694

Vasilakopoulos P., Maravelias C.D., Tserpes G. 2014. The alarming decline of Mediterranean fish stocks. Current Biology 24 (14): 1643-1648. DOI: 10.1016/j. cub.2014.05.070

Villasante S., Antelo M., Christou M., Fauconnet L., Frangoudes K., Moynou F., Morato T., Pita C., Pita P., Stergiou K.I., Teixeria C., Tserpes G., Vassilopoulou V. 2019. The implementation of the landing obligation in small-scale fisheries of southern European Union countries. Pp.88-108. DOI: 10.1007/978-3-030-03308-8 5 In: Uhlmann S., Ulrich C., Kennelly S (eds.) The European landing obligation: Reducing discards in complex multi-species and multijurisdictional fisheries. Springer, Cham, Switzerland. DOI: $10.1007 / 978-3-030-03308-8$

Received: 12 March 2019

Accepted: 16 July 2019

Published electronically: 15 December 2019 